\title{
Minimizing Central-Local Relation using Local Resource Mobilization in Bangladesh
}

\author{
Fakhrul Islam \\ Assistant Professor, Department of Public Administration \\ Shahjalal University of Science and Technology, Sylhet, Bangladesh \\ Email: fakhrul.bs11@gmail.com, Phone: +8801710186064
}

Accepted: May 27, 2015

Doi:10.5296/ jpag.v5i2.7561 URL: http://dx.doi.org/10.5296/ jpag.v5i2.7561

\begin{abstract}
Union Parishad (UP) is the lowest tier of rural local government plays an important role to fulfill the demand and aspiration of local people and the overall development of the country. But UP (Union Parishad) in Bangladesh are yet to perform optimal local revenue mobilization. This paper examines opportunities and constraints local revenue trend and performance and the problems of revenue mobilization and to provide a strategy for reducing dependency on the central government and enhancing the revenue collection of Union Parishad. The analysis is exemplified by exploratory and descriptive method and social survey has been arranged for collecting data and information from Unions of Bajitpur upazilla under Kishoregonj district. A general conclusion emerging from the study is that despite revenue potentials, weak revenue administration, less power to create new source of revenue, lack of people's participation, lack of permanent tax collector and political and central control are the major impediments on local resource mobilization. This study tries to explore potential area of resource and suggested to control political pressure, to set up campaign and workshop on resource mobilization and bringing awareness among the citizens as well as UP officials.
\end{abstract}

Keywords: Local Resources, Mobilization, Dependency, Central Government, Potential Income Area. 


\section{Introduction}

The decentralization of development policies and programmes to local institutions has been emphasized in developing countries due to the increasing recognition that expansive administrative responsibilities cannot be carried out by the central government alone, that socioeconomic progress requires active people's participation, that resource mobilization necessitates local initiatives, and that devolution of power is a precondition for a democratic mode of governance (Haque1997). Local government institutions of Bangladesh play a key role in the development of the rural economy. Bangladesh Constitution (Article 59 and 60) ${ }^{\mathbf{1}}$ has given the main foundation of the role, structure and functions of local government (Ahmed, 2010). With the diminishing role of the state in programs such as poverty eradication, employment generation, public health, and basic education, the role of local institutions in addressing the needs of local communities has increased (Haque,1997). Their contribution towards poverty alleviation and promotion of economic growth is vital for national development as well as local level development. The Union Parishad ${ }^{2}$ is the oldest and the only representative local government institution that has had a continuous existence since the 1880s but it has its limitations and resource constraints (Ahmed, 2010). Union Parishads are mandated to assess and collect local tax revenues but It cannot exercising their authority or responsibilities fully in this area (UNDP, 2009). The loyalty of this institutions to central government may not be sufficient for, may even be antithetical to, their accountability to the local communities. Very often, due to the politicization and bureaucratization of local institutions and the imposition of various programs on them by the central government, this institution can hardly be responsive to the local needs. This overwhelming power of the central government over local authorities is usually due to their extreme dependence on the state for resources, technologies, and infrastructure (Haque,1997). Representatives of many Union Parishad seem to think that by levying local taxes to the full possible extent, they risk losing their popularity and future electability and local elected officials are not all equally familiar with the rules for assessing and collecting taxes. Own-source revenues can provide a very effective and accountable Union Parishad-citizen relationship. Mobilization of own-source revenue promotes accountability and high levels of accountability also make citizens more willing to pay for services. A sound revenue system for local governments is an essential precondition for the success of fiscal decentralization (Bird 2010; Martinez Vazquez and Smoke 2010; Olowuand Wunsch2003). Local Government in Bangladesh has been provided with several sources of revenue that come from own revenues primarily come from property tax, business licenses and user fees through which can be utilized for the maintenance of the Union Parishad as well as the initiation of developmental projects (UNDP, 2009). This will eventually pave the way for establishing an effective and vibrant local

\footnotetext{
1 Article 59:Local Government (1)Local Government in every administrative unit of the Republic shall be entrusted to bodies, composed of persons elected in accordance with law.(2)Everybody such as is referred to in clause(1)shall, subject to this constitution and any other law, perform within the appropriate administrative unit such functions as shall be prescribed by Act of parliament, which may include functions relating to-(a)administration and the work of public officers;(b)the maintenance of public order;(c) the preparation and implementation of plans relating to public services and economic development. Article 60:power of local government bodies.-For the purpose of giving full effect to the provisions of article 59 parliament shall, by law, confer powers on the local government bodies referred to in that article, including power to impose taxes for local purposes, to prepare their budgets and to maintain funds.
} 
government system ${ }^{3}$. Adequate and appropriate administrative structures are developed and that proper training is provided to enhance the knowledge and skills of local leaders and to enable the councils to perform the task of revenue collection efficiently.

\section{Aim and Objective of the Study}

The study aimed to examine the capacity and to draw a proposition to dwindle dependency of Union Parishad on central Government through local resource mobilization in Bangladesh.

The study pursuit the following objectives to reach the aim;

1. To examine the existing process, procedures and the problems of resource mobilization at Union Parishad.

2. To sort out a strategic outline to reduce over dependence dependency on the central government through enhancing the revenue collection of Union Parishad

\section{Literature Review}

A great amount of important information was found about the evolution of the local government in Bangladesh and about the changes made to these institutions in the past in respect to its structure, functions and duties. The issue of Inadequate finance and personnel in the UP were mentioned and suggestion for improvement was made as-"The tax base of the local bodies has to be sufficiently enlarged. The local bodies, in their turn, should make the best use of the tax base within their competence. The management of local bodies should be made more efficient by recruiting qualified persons and organizing skill-oriented training for the existing employees. The terms and conditions of the services should also be made attractive. Some of the tax items, yielding substantial revenue, may be transferred from the central government to the local bodies. Revenue sharing with the central government may be an effective way of increasing the income of the local bodies. The rate of taxes on non-income based items should be increased in proportion to the rate of inflation. In the case of property based taxes, the valuation of property should be revised in proportion to the rate of inflation. So the same rate of tax should be able to yield more revenue (Siddiqui, Kamal, 2005).

Local self-government is one of the important tiers of democratic government but it cannot perform their task fruitfully for various constraints. Financial constraints are one of them because to run such kind of government requires a lot of money but it is quite possible to raise this fund adequately. The main income source of local government is central government grants although they have also power to raise their own fund by imposing tax on general people but these money are quite little to conduct the development activities in the local areas so they almost depends on the government grants. Even the government grant is the main income source of local government but the central government cannot allot the fund required every time. As a result the development activities sometimes remain incomplete. If

\footnotetext{
3 Khan,M,M,UP Tax Behavior. (Available at http://www.dwatch-bd.org/UP\%20tax\%20Behavior.pdf accessed on 17-03-2013).
} 
the general people participate in the development activities of the government then the real development of the country will be achieved by local government. But the maximum time the general people are not interested to participate in the development activities. But there is no details description about resource mobilization, how Union parishad mobilize their resources (Rahman, Maksadur, 1995).

The various interpretation given to 'Decentralization' over the past three decades are by now fairly well-known to scholars and practitioners to public administration. One of the main issues in considering decentralization is the possibility, indeed the probability that local institutions will be controlled and exploited by more advanced sections of the rural community. The subject of "resource mobilization" and "resources management "should be addressed concurrently, because the willingness of rural people to contribute resources-their money and labor, but also ideas and managerial skill-crucially depends on how well those resources are utilized. It will do little good to start resource flows that cannot be sustained because people have no confidence that the resources will be used productively and honestly. In this book they also mentioned-local resource mobilization prospects critically depend on two factors one is building supportive institution and another is relating fiscal transfers to performance. Local authorities claim that they lack sufficient taxing power, which is the reason why they could generate only so many revenues. This analysis based on the broad issues relating to the problems and prospects of resource mobilization from theoretical point of view and then examines the same in the context of Bangladesh. But it is not very clear how the source of any fiscal reform at the local level depends on changes in local level institutions simply by making them more responsive to the needs of the poor (Hye, Hasnat Abdul, 1985).

The present situation of rural local resource mobilization in Bangladesh required making suggestion of possible policy initiatives in enhancing the raising of local resources. The low level of domestic resource mobilization for public has long been recognized as a serious constraint on development in Bangladesh. The third five year plan the ratio of total taxes to gross domestic product has been consistently less in Bangladesh than in other less developed countries. Over the past decades local government in recent years generated about 70 percent of their rather modest expenditures through local taxes and non-tax receipts, with the remainder coming from central government grants. In chapter two, it is found a brief backgrounds sketch of local resource mobilization, focusing on its relationship to decentralization in Bangladesh. An overview of past experience with raising government revenue from the rural areas includes a discussion of the possible sources of income from the countryside for both the central and local government. There is very little interest in tax collection at either local or central level, even if they were interested to mobilize more resources for development purposes, there is no real structure or mechanism through which it can spend such revenue (Blair, Harry W, 1989).

Union Parishad Training Manual is a government prescribed detailed guidebook for the Union Parishad to operate. All necessary rules and regulations are added in it to enable the UP to operate accordingly. In this book, "Real development has not been achieved because in a top-down method, the demand felt by the people is not reflected and there is no participation and sharing of the people in making plans. Union Parishad playas critical role in 
the development of local level .In this context, importance has been given in local level participatory and local resource mobilization. The source of imposing tax of Union parishad is determined by the central Government. The central Government bears the salary of up officials and honorarium of up members. In most cases for financial support they have to dependent on central Government (NILG), 2003).

\section{Research Method}

This study has been conducted followed by exploratory method as study objective is to discover the ways to reduce dependency and show insights of Union Parishad as well as followed by descriptive design that deploy with social survey method to collect information providing additional information and various elements of the study problem. A combination of quantitative and qualitative methods has been employed for the study. In this study qualitative approach has been used to analyze the opinion of the respondents through the conducting several case study to provide analysis and findings in a comparative perspective and then to generalize and quantitative method has been used to classify the opinion of the respondents presented in the tables and the responses are shown in percentage. Qualitative data in the form of opinions and multiple responses are used to complement the quantitative analysis. Deductive reasoning strategy has been followed in this study because the study started with a very broad spectrum of local governance and Union Parishad making the way down to measures the scope and opportunity to reduce dependency from central government through its own resource mobilization and then this study lead to detect the pattern of existing local resources system from field data, formulate some tentative suggestions; and finally ends up developing some general conclusion.

\subsection{Area of the Study and Sample Size}

Considering some reasonable advantage, Three Union Parishad namely, Hilochia Union, Sararchar Union and Pirijpur Union under Bajitpur upazila under Kishoregonj District in Dhaka Division has been selected as study area. Bajitpur is located at $24.2167^{\circ} \mathrm{N} 90.9583^{\circ} \mathrm{E}$. It has 35051 units of house hold and total area $193.76 \mathrm{~km}^{2}$. Bajitpur Upazila consists of 1 Municipality, 11 Unions, 9 Wards, 115 Mauzas/Mahallas, 178 villages ${ }^{4}$. The following Map-1 shown the study area;

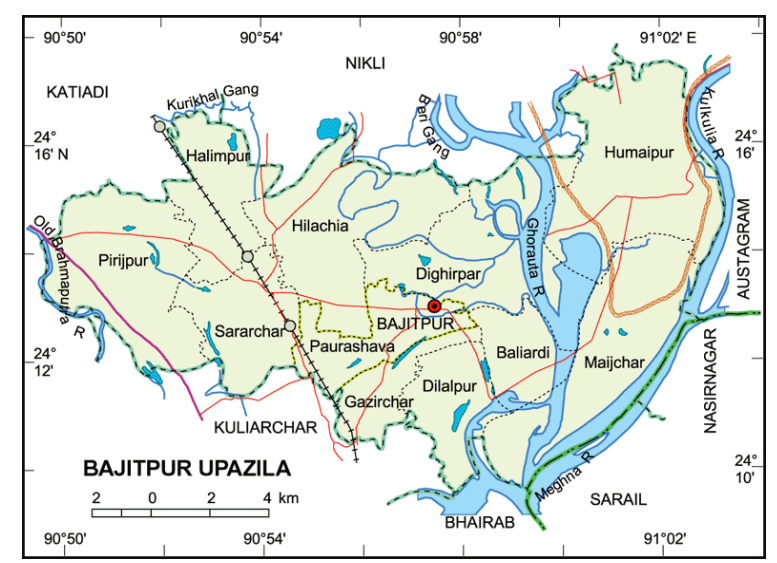

\footnotetext{
${ }^{4}$ http://en.wikipedia.org/wiki/Bajitpur_Upazila $\quad$ accessed on, 28.04.20123.
} 


\section{Macrothink}

Map-1: The Study Area

The population is identified as the members, officials of Union Parishad and mass people as the beneficiary or benefactor people of selected Union Parishad but a particular number of individuals are considered as unit of analysis from the total population. In this study, the 92 respondents were selected as sample of this study using two sampling method, first 32 respondent were selected using stratified sampling method where 3 were Chairman of Union Parisahd, 21 were member including both male and female and 8 were the administrative staff who were selected using stratified random sample method, on the other hand, 60 voters from three Union Parisahd were selected using non-probably purposive method.

\section{Data Analysis}

\subsection{Data from People Representative and Officials}

Table-5.1.1 Scope of utilize sufficient resources at Local Level by UP

\begin{tabular}{|lll|}
\hline Type of responses & Number & Percentage (\%) \\
Yes & 5 & $15.625 \%$ \\
No & 25 & $78.125 \%$ \\
No Comment & 2 & $6.25 \%$ \\
Total & 32 & $100 \%$ \\
\hline
\end{tabular}

Source: Field Data Collected from Hilochia, Pirijpur and Sararchar Union of Bajitpur upazila on October-December, 2014

Table 5.1.1 shows that a large majority of respondents $(78.125 \%)$ assumed that scope of utilizing local resources mobilization at Union Parishad are not sufficient. In contrast a low portion of the respondents $(15.625 \%)$ assumed the opposite. 
Table- 5.1.2: Potential variety of Local Resources

\begin{tabular}{|c|c|c|c|c|c|c|c|c|c|c|}
\hline \multirow[t]{2}{*}{$\begin{array}{l}\text { Kinds of Local } \\
\text { Resources }\end{array}$} & \multicolumn{2}{|c|}{$\begin{array}{l}\text { Available and } \\
\text { Potential }\end{array}$} & \multicolumn{2}{|c|}{$\begin{array}{l}\text { Available but } \\
\text { Partially } \\
\text { Potential }\end{array}$} & \multicolumn{2}{|c|}{$\begin{array}{l}\text { May be } \\
\text { Available } \\
\text { and } \\
\text { Potential }\end{array}$} & \multicolumn{2}{|c|}{ Not useful } & \multirow[t]{2}{*}{ Total } & \multirow[t]{2}{*}{$\%$} \\
\hline & $\mathrm{N}$ & $\%$ & $\mathrm{~N}$ & $\%$ & $\mathrm{~N}$ & $\%$ & $\mathrm{~N}$ & $\%$ & & \\
\hline $\begin{array}{lr}\text { Natural or } & \text { Human } \\
\text { Resources } & \text { (e.g. } \\
\text { Mineral, } & \text { forest, } \\
\text { entrepreneur) } & \end{array}$ & 00 & $0.00 \%$ & 15 & $\begin{array}{l}46.875 \\
\%\end{array}$ & 12 & $37.5 \%$ & 5 & $15.62 \%$ & 32 & $100 \%$ \\
\hline $\begin{array}{l}\text { Physical and } \\
\text { Infrastructural } \\
\text { resources } \\
\text { Markets, Agricultural } \\
\text { Lands, Home Lands, } \\
\text { etc) }\end{array}$ & 22 & $\begin{array}{l}68.75 \\
\%\end{array}$ & 6 & $18.75 \%$ & 4 & $12.5 \%$ & 00 & $0.00 \%$ & 32 & $100 \%$ \\
\hline $\begin{array}{l}\text { Financial Resources } \\
\text { ( Taxes, fees, tolls, } \\
\text { Development funds) }\end{array}$ & 30 & $\begin{array}{l}93.75 \\
\%\end{array}$ & 2 & $6.25 \%$ & 00 & $0.00 \%$ & 00 & $0.00 \%$ & 32 & $100 \%$ \\
\hline
\end{tabular}

Source: Field Data Collected from Hilochia, Pirijpur and Sararchar Union of Bajitpur upazila on October-December, 2014.

Table-5.1.2 shows that there is no available amount of the natural or human resources (e.g. mineral, forest, entrepreneur) where $68.75 \%$ of the respondent said available physical and infrastructural resources and the large majority $93.75 \%$ of respondent said available financial resources ( taxes, fees, tolls, development funds). On the other hand, $46.875 \%$ of the respondent noted the natural or human resources (e.g. mineral, forest, entrepreneur) and $18.75 \%$ of the respondent mentioned Physical and Infrastructural resources (e.g., Markets, Agricultural Lands, Home Lands, etc) and also $6.25 \%$ of the respondent mentioned Financial Resources ( Taxes, fees, tolls, Development funds) as available resource in local area but not effective. Some local resources were unknown and potential to use to the respondent as $15.62 \%$ of the respondent said Natural or Human Resources (e.g. Mineral, forest, entrepreneur). 


\section{Macrothink}

Table-5.1.3: Major Sources of Income of Union Parishad

\begin{tabular}{|c|c|c|c|c|c|c|c|c|c|c|}
\hline \multirow[t]{2}{*}{$\begin{array}{l}\text { Sources of } \\
\text { Income }\end{array}$} & \multicolumn{2}{|c|}{ Satisfactory } & \multicolumn{2}{|c|}{$\begin{array}{l}\text { Not } \\
\text { Satisfactory }\end{array}$} & \multicolumn{2}{|c|}{$\begin{array}{l}\text { Partial } \\
\text { Satisfactory }\end{array}$} & \multicolumn{2}{|c|}{ No Comments } & \multirow[t]{2}{*}{ Total } & \multirow[t]{2}{*}{$\%$} \\
\hline & $\mathrm{N}$ & $\%$ & $\mathrm{~N}$ & $\%$ & $\mathrm{~N}$ & $\%$ & $\mathrm{~N}$ & $\%$ & & \\
\hline $\begin{array}{l}\text { Registrations of } \\
\text { land and other } \\
\text { issues }\end{array}$ & 30 & $93.75 \%$ & 2 & $6.25 \%$ & 00 & $0.00 \%$ & 00 & $0.00 \%$ & 32 & $100 \%$ \\
\hline Certificates & 00 & $0.00 \%$ & 00 & $0.00 \%$ & 32 & $100 \%$ & 00 & $0.00 \%$ & 32 & $100 \%$ \\
\hline $\begin{array}{l}\text { Leasing of } \\
\text { market }\end{array}$ & 00 & $0.00 \%$ & 25 & $\begin{array}{l}78.125 \\
\%\end{array}$ & 5 & $15.625 \%$ & 2 & $6.25 \%$ & 32 & $100 \%$ \\
\hline $\begin{array}{l}\text { Issuing Trade } \\
\text { license }\end{array}$ & 32 & $100 \%$ & 00 & $0.00 \%$ & 00 & $0.00 \%$ & 00 & $0.00 \%$ & 32 & $100 \%$ \\
\hline $\begin{array}{l}\text { Fees ( Fair, } \\
\text { exhibitions, } \\
\text { sports etc) }\end{array}$ & 00 & $0.00 \%$ & 00 & $0.00 \%$ & 32 & $100 \%$ & 00 & $0.00 \%$ & 32 & $100 \%$ \\
\hline $\begin{array}{l}\text { Leasing of } \\
\text { wetland } \\
\text { (Jolmohal) }\end{array}$ & 00 & $0.00 \%$ & 20 & $62.5 \%$ & 10 & $31.25 \%$ & 2 & $6.25 \%$ & 32 & $100 \%$ \\
\hline $\begin{array}{l}\text { Land } \\
\text { transformation } \\
\text { fee }\end{array}$ & 00 & $0.00 \%$ & 32 & $100 \%$ & 00 & $0.00 \%$ & 00 & $0.00 \%$ & 32 & $100 \%$ \\
\hline $\begin{array}{l}\text { Birth } \\
\text { registration fee }\end{array}$ & 28 & $87.5 \%$ & 4 & $12.5 \%$ & 00 & $0.00 \%$ & 00 & $0.00 \%$ & 32 & $100 \%$ \\
\hline Tax,fees,tools, & 32 & $100 \%$ & 00 & $0.00 \%$ & 00 & $0.00 \%$ & 00 & $0.00 \%$ & 32 & $100 \%$ \\
\hline
\end{tabular}

Source: Field Data Collected from Hilochia, Pirijpur and Sararchar Union of Bajitpur upazila October-December, 2014

In the table- 5..1.3 above noted that the majority of the respondent said satisfied about income of union parishad. a large $93.75 \%$ of the respondent reported here satisfied on registrations of land and other issues, $87.5 \%$ of the respondent about birth registration fee and absolute 


\section{Macrothink}

Journal of Public Administration and Governance

ISSN 2161-7104

2015, Vol. 5, No. 2

majority $100 \%$ of the respondent on issuing trade license and tax,fees,tools. On the downside majority of the respondent were not satisfied in differ ten means of income as the table reported two-third $78.125 \%$ of the respondent on Leasing of market, $62.5 \%$ of the respondent on Leasing of wetland (Jolmohal) and absolute 100\% of the respondent on Land transformation fee were not satisfied.

Table-5.1.4: Barrier in Maintaining Local Resources

\begin{tabular}{|c|c|c|c|c|c|c|c|c|c|c|}
\hline \multirow[t]{2}{*}{$\begin{array}{l}\text { Types of } \\
\text { Response }\end{array}$} & \multicolumn{2}{|c|}{ Excessive } & \multicolumn{2}{|c|}{$\begin{array}{l}\text { Not } \\
\text { Excessive }\end{array}$} & \multicolumn{2}{|c|}{ Not at all } & \multicolumn{2}{|c|}{ No Comments } & \multirow[t]{2}{*}{ Total } & \multirow[t]{2}{*}{$\%$} \\
\hline & $\mathrm{N}$ & $\%$ & $\mathrm{~N}$ & $\%$ & $\mathrm{~N}$ & $\%$ & $\mathrm{~N}$ & $\%$ & & \\
\hline $\begin{array}{l}\text { Lack of } \\
\text { cooperation } \\
\text { among officials }\end{array}$ & 10 & 31.25 & 18 & $\begin{array}{l}56.2 \\
5\end{array}$ & 00 & $0.00 \%$ & 2 & $6.25 \%$ & 32 & $100 \%$ \\
\hline $\begin{array}{l}\text { Lack of proper } \\
\text { inspection }\end{array}$ & 00 & $\begin{array}{l}0.00 \\
\%\end{array}$ & 30 & $\begin{array}{l}93.7 \\
5\end{array}$ & 2 & $6.25 \%$ & 00 & $0.00 \%$ & 32 & $100 \%$ \\
\hline $\begin{array}{l}\text { Lack of } \\
\text { cooperation } \\
\text { among general } \\
\text { people }\end{array}$ & 15 & $\begin{array}{l}46.87 \\
5\end{array}$ & 10 & $\begin{array}{l}31.2 \\
5\end{array}$ & 5 & $\begin{array}{l}15.625 \\
\%\end{array}$ & 2 & $6.25 \%$ & 32 & $100 \%$ \\
\hline Political pressure & 28 & $\begin{array}{l}87.5 \\
\%\end{array}$ & 2 & 6.25 & 00 & $0.00 \%$ & 2 & $6.25 \%$ & 32 & $100 \%$ \\
\hline $\begin{array}{l}\text { Lack of } \\
\text { manpower }\end{array}$ & 21 & $\begin{array}{l}65.62 \\
5\end{array}$ & 8 & 25 & 3 & $\begin{array}{l}9.375 \\
\%\end{array}$ & 00 & $0.00 \%$ & 32 & $100 \%$ \\
\hline $\begin{array}{l}\text { Legally assigned } \\
\text { sources is not } \\
\text { sufficient }\end{array}$ & 19 & $\begin{array}{l}59.37 \\
5\end{array}$ & 13 & $\begin{array}{l}40.6 \\
25\end{array}$ & 00 & $0.00 \%$ & 00 & $0.00 \%$ & 32 & $100 \%$ \\
\hline
\end{tabular}

Source: Field Data Collected from Hilochia, Pirijpur and Sararchar Union of Bajitpur upazila October-December, 2014

From this table you see that different types of obstacle people representatives and concern officials faced in maintaining local resources. Reported here is that slightly major portion 56.25of the respondent mentioned about sound coordination among the officials in downside $31.25 \%$ of the respondent mentioned excessive disco-ordination exist here at UP, the absolute majority $93.75 \%$ of the respondent noticed absence of proper inspection at UP, $46.875 \%$ of the respondent noticed about gap between the general people with their representatives, 
$87.5 \%$ of the respondent noticed about political pressure create barrier while taking their decision, $65.625 \%$ of the respondent in the table above noticed about shortage of sufficient manpower and $59.375 \%$ of the respondent mentioned that legally assigned source of income found not sufficient (Table- 5..1.4).

Table-5.1.5: Problems in Collecting Tax/Tolls/Fees

\begin{tabular}{|lll|}
\hline Types of response & Number & Percentage (\%) \\
\hline Lack of awareness & 15 & $46.875 \%$ \\
\hline Shortage of manpower & 5 & $15.625 \%$ \\
Poverty of mass people & 2 & $6.25 \%$ \\
\hline Negligence of tax payer & 10 & $31.25 \%$ \\
Total & 32 & $100 \%$ \\
\hline
\end{tabular}

Source: Field Data Collected from Hilochia, Pirijpur and Sararchar Union of Bajitpur upazila October-December, 2014

From the observation the table- 5..1.5 shows that majority $46.875 \%$ of the respondent believed that the main problem in collecting tax/tolls/fees were lack of awareness while the lowest $6.25 \%$ of the respondent said poverty, and $15.625 \%$ of the respondent identified lack of manpower, and the rest $31.25 \%$ of the respondent referred negligence of tax payer were the problem in collecting tax/tolls/fees at UP.

Table- 5.1.6: Problems in Leasing of Market and Wetlands

\begin{tabular}{|lll|}
\hline Type of responses & Number & Percentage (\%) \\
Yes & 25 & $78.125 \%$ \\
\hline No & 4 & $12.5 \%$ \\
No Comment & 3 & $9.375 \%$ \\
Total & 32 & $100 \%$ \\
\hline
\end{tabular}

Source: Field Data Collected from Hilochia, Pirijpur and Sararchar Union of Bajitpur upazila October-December, 2014

Table-6.1.6 shows that a large majority $79.125 \%$ of the respondent mentioned UP suffered with problem in leasing Hatbazar and Jalmahals where $12.5 \%$ of the respondent noticed on 
smoothness in working in leasing Hatbazar and Jalmahals.

Table-5.1.7: Commission of Land Transfer Rate for UP Fund (increasing like 1\% or 2\%)

\begin{tabular}{|lll|}
\hline Type of responses & Number & Percentage \\
\hline Yes & 32 & $100 \%$ \\
\hline No & 00 & $00 \%$ \\
\hline No Comment & 00 & $00 \%$ \\
\hline Total & 32 & $100 \%$ \\
\hline
\end{tabular}

Source: Field Data Collected from Hilochia, Pirijpur and Sararchar Union of Bajitpur upazila October-December, 2014

From the study observation, the whole thirty-two of the participants were agree to increae land transfer rate increases about $1 \%$ or $2 \%$ then it will be beneficiary for Union Parishad (Table-5.1.7).

Table-5.1.8. Political and administrative threat to mobilize local resources

\begin{tabular}{|lll|}
\hline Types of response & Number & Percentage (\%) \\
\hline Yes & 29 & $90.625 \%$ \\
\hline No & 3 & $9.375 \%$ \\
\hline No Comment & 0 & $0.00 \%$ \\
\hline Total & 32 & $100 \%$ \\
\hline
\end{tabular}

Source: Field Data Collected from Hilochia, Pirijpur and Sararchar Union of Bajitpur upazila October-December, 2014

The absolute majority of the participant, $90.625 \%$ of the respondents agreed on taking their decision at UP with influenced by the political and administrative pressure and introduction (Table-5.1.8). 


\section{Macrothink}

Table-5.1.9: Problems in Development Projects Implementation

\begin{tabular}{|c|c|c|}
\hline Types of response & Number & Percentage $(\%)$ \\
\hline $\begin{array}{l}\text { Internal conflict among UP } \\
\text { representatives }\end{array}$ & 3 & $9.375 \%$ \\
\hline $\begin{array}{l}\text { Lack of co-ordination among UP } \\
\text { members. }\end{array}$ & 2 & $6.25 \%$ \\
\hline Central Government Involvement & 7 & $21.875 \%$ \\
\hline Local political leaders influence & 20 & $62.5 \%$ \\
\hline Total & 32 & $100 \%$ \\
\hline
\end{tabular}

Source: Field Data Collected from Hilochia, Pirijpur and Sararchar Union of Bajitpur upazila October-December, 2014

It appears from the Table-5.1.9 large numbers of people (62.5\%) said local and political influence creates problems while undertaking and implementing development projects and $21.875 \%$ said central government involvement, on the other hand $9.375 \%$ said presence of internal conflict among UP representatives and rest $6.25 \%$ marked existing lack of co-ordination among UP members.

Table-5.1.10: Present Financial Strength of UP to bear self-expense

\begin{tabular}{|lll|}
\hline Types of response & Number & Percentage (\%) \\
Yes & 4 & $12.5 \%$ \\
\hline No & 28 & $87.5 \%$ \\
No Comment & 0 & $0.00 \%$ \\
Total & 32 & $100 \%$ \\
\hline
\end{tabular}

Source: Field Data Collected from Hilochia, Pirijpur and Sararchar Union of Bajitpur upazila October-December, 2014

From the field observation it has been found in the table above that a large number of people about $87.5 \%$ noticed that UP don't have available balance to bear self-expense in contrary, $12.5 \%$ of the respondent were found auspicious to bear self-expenses (Table-5.1.10). 


\section{Ml Macrothink}

Table-5.1.11: Initiatives of Making Self Reliance of Union Parishad(UP)

\begin{tabular}{|c|c|c|c|c|c|c|c|c|}
\hline \multirow{2}{*}{$\begin{array}{l}\text { Types of } \\
\text { Response }\end{array}$} & \multicolumn{2}{|c|}{ Yes } & \multicolumn{2}{|l|}{ No } & \multicolumn{2}{|c|}{ No Comment } & \multirow[t]{2}{*}{ Total } & \multirow[t]{2}{*}{$\%$} \\
\hline & $\mathrm{N}$ & $\%$ & $\mathrm{~N}$ & $\%$ & $\mathrm{~N}$ & $\%$ & & \\
\hline $\begin{array}{l}\text { Provision of } \\
\text { permanent tax } \\
\text { collector }\end{array}$ & 30 & $93.75 \%$ & 00 & $0.00 \%$ & 2 & $6.25 \%$ & 32 & $100 \%$ \\
\hline $\begin{array}{l}\text { Improvement } \\
\text { of Land } \\
\text { Management }\end{array}$ & 19 & $59.375 \%$ & 10 & $31.25 \%$ & 3 & $9.375 \%$ & 32 & $100 \%$ \\
\hline $\begin{array}{l}\text { Span to extend } \\
\text { existing local } \\
\text { income source }\end{array}$ & 32 & $100 \%$ & 00 & 00 & 00 & 00 & 32 & $100 \%$ \\
\hline $\begin{array}{l}\text { Reducing } \\
\text { administrative } \\
\text { control }\end{array}$ & 23 & $71.875 \%$ & 6 & $18.75 \%$ & 3 & $9.375 \%$ & 32 & $100 \%$ \\
\hline $\begin{array}{l}\text { Generating } \\
\text { new income } \\
\text { e.g. land } \\
\text { registration } \\
\text { fees, market } \\
\text { auction fees }\end{array}$ & 28 & $87.5 \%$ & 00 & $0.00 \%$ & 4 & $12.5 \%$ & 32 & $100 \%$ \\
\hline $\begin{array}{l}\text { Reduce local } \\
\text { and central } \\
\text { political } \\
\text { involvement }\end{array}$ & 30 & $93.75 \%$ & 00 & $0.00 \%$ & 2 & $6.25 \%$ & 32 & $100 \%$ \\
\hline
\end{tabular}

Source: Field Data Collected from Hilochia, Pirijpur and Sararchar Union of Bajitpur upazila October-December, 2014

From this table-5..1.11 you see that various initiatives have been rated by the participant in order to make UP as self-reliant. A large majority $93.75 \%$ of the respondent suggested Provision of permanent tax collector, $59.375 \%$ of the respondent mentioned Improvement of Land Management, all of the respondent identified extending span of control in local income source, $71.875 \%$ of the respondent favored in Reducing administrative control, $87.5 \%$ of the respondent mentioned generating new income e.g. land registration fees, market auction fees 
and $93.75 \%$ the respondent suggested reducing local and central political involvement as reform initiatives to make UP a self-reliant.

Table -5.1.12: Level of Confidence to use own resources

\begin{tabular}{|lll|}
\hline Confidence Level & Number & Percentage (\%) \\
\hline Low & 03 & 9.37 \\
Moderate & 05 & 15.62 \\
Slightly Upper Moderate & 09 & 28.12 \\
Slightly High & 08 & 25.00 \\
High & 07 & 21.87 \\
Total & 32 & 100 \\
\hline
\end{tabular}

Source: Field Data Collected from Hilochia, Pirijpur and Sararchar Union of Bajitpur upazila October-December, 2014

Level of confidence to use own resources is expressed in table-5..1.12 as percentage and represents how much confidence is there in the concern people. Slightly upper moderate level of confidence has been found as the highest responses (28.12\%) from the respondents, then confidence level $25 \%$ was found slightly high and only $21.87 \%$ was found as having high confidence.

\subsection{Analysis of Data from Mass People:}

Table-5.2.1: Public Satisfaction on UP Resource Mobilization Process

\begin{tabular}{|lll|}
\hline Types of response & Number & Percentage \\
\hline Yes & 15 & $16.67 \%$ \\
\hline No & 50 & $83.33 \%$ \\
No Comment & 00 & $0.00 \%$ \\
Total & 60 & $100 \%$ \\
\hline
\end{tabular}

Source: Field Data Collected from Hilochia, Pirijpur and Sararchar Union of Bajitpur upazila October-December, 2014 


\section{Macrothink}

Table-5.2.1, a large majority of the respondent (83.33\%) were found not satisfied with existing process and procedure of resource mobilization. In contrast a low portion of the respondents $(16.67 \%)$ of the respondent were found on the other hand, satisfied with the resources mobilization process of UP.

Table-5.2.1: Public confidence on different aspects of making UP self reliant

\begin{tabular}{|c|c|c|c|c|}
\hline \multirow[t]{2}{*}{ Type of Response } & \multicolumn{2}{|c|}{ Yes } & \multicolumn{2}{|c|}{$\mathrm{NO}$} \\
\hline & $\mathrm{N}$ & $\%$ & $\mathrm{~N}$ & $\%$ \\
\hline $\begin{array}{l}\text { Legal strength } \\
\text { require to collect } \\
\text { fees, tools and } \\
\text { limited tax locally }\end{array}$ & 42 & 70.00 & 18 & 30.00 \\
\hline $\begin{array}{l}\text { simplifying rate } \\
\text { structures and } \\
\text { collection } \\
\text { procedures }\end{array}$ & 47 & 78.33 & 13 & 21.67 \\
\hline $\begin{array}{l}\text { Circulate the list of } \\
\text { fees, charges and } \\
\text { tools }\end{array}$ & 32 & 53.33 & 28 & 46.67 \\
\hline $\begin{array}{l}\text { Political } \\
\text { Leadership and } \\
\text { Good } \\
\text { Governance }\end{array}$ & 15 & 25.00 & 45 & 75.00 \\
\hline $\begin{array}{l}\text { Improvement, } \\
\text { Productivity } \\
\text { and } \\
\text { Accountability }\end{array}$ & 32 & 53.33 & 18 & 46.67 \\
\hline $\begin{array}{l}\text { Meeting } \\
\text { infrastructure } \\
\text { needs }\end{array}$ & 39 & 65.00 & 21 & 35.00 \\
\hline $\begin{array}{l}\text { Sharing land } \\
\text { registration fees }\end{array}$ & 37 & 61.66 & 23 & 38.34 \\
\hline $\begin{array}{l}\text { Share from Market } \\
\text { and Water body } \\
\text { auction fees }\end{array}$ & 39 & 65 & 21 & 35 \\
\hline $\begin{array}{l}\text { Monitoring } \\
\text { Revenue } \\
\text { Collections Process }\end{array}$ & 49 & 81.66 & 11 & 18.34 \\
\hline $\begin{array}{l}\text { Supportive } \\
\text { Central-Local }\end{array}$ & 51 & 85.00 & 09 & 15.00 \\
\hline
\end{tabular}


Relation

Source: Field Data Collected from Hilochia, Pirijpur and Sararchar Union of Bajitpur upazila October-December, 2014

Table-5.2.1 shows public confidence on different aspects of making UP self reliant where supportive central-local relation has been identified by highest number 51 of the respondents; Monitoring Revenue Collections Process has been identified by the second highest number 49 of the respondents and simplifying rate structures and collection procedures has been identified third highest number 47 of the respondent as an important aspect by which UP can be self reliant. On the downside, political leadership and good governance was the lowest prioritized aspect by the respondent.

\section{Qualitative data Analysis}

\subsection{Case Studies:}

\section{Case Study-1}

Moin Uddin (Pseudonym) is an employee of Union Parishad and has been working as the secretary (chief of UP administration) of the Hilochia Union Parishad for fifteen years. He was asked several questions in different issues on self reliance of local government to have a insight of fact from his long experience. On the issue of central-local existing situation, he pointed out that absence of a logical step between central and local government is to examine their respective roles as these are different in Bangladesh and is laid out in constitutional arrangements which also provide the legal means for resolving dependency. Then he mentioned problems arise when they are at odds in role. Specifically he was asked how dependency can be reduced or is it possible to remove? Enabling local authorities to retain a significant proportion of the revenue rates generated in their area will provide a strong financial incentive for them to promote local economic growth. Therefore, revenue collection system must go under reform; to have a permanent tax collector at local area, the resources which UP can monitor and control and utilize. The distribution of business rate tax revenues should not be equal as every UP in Bangladesh are not same as some area is developed and some are geographically in remote area and underdeveloped. So the its not possible to make remote UP financially self reliant which can very possible by UP which located in the developed area. He emphasized on categorization of UP based on financial strength. He as then asked, should power of imposing tax be permitted to UP? He noticed people awareness and responsiveness is the key to implement imposing local tax and fees. Besides, the influence of local political leaders identified as a grand barrier to organize resources at local level. The source of local income is not sufficient to carry out regular work and the question of operating development activities is impossible so it must depend on central government grant. Specifically he mentioned that fiscal deficits and other investment priorities have significantly reduced central government transfers to local municipalities, limiting the provision of basic services can be the way of reducing dependency of UP to central government. At the end, he added, Up will be able to run with its own resources, if increasing 
or enhance own source revenues through existing sources, UP should entail identifying the specific sources; improving the cadastres and rolls of the registry; updating the rates; improving billing and collection efficiency; reducing arrears and adopting sound financial management practices with regard to enforcement; and creating client or consumer oriented strategies for issuance of certificates.

\section{Case Study-2}

Nazrul Islam (Pseudonym) is a chairman elected by people of Pirijpur Union Parishad for the second time. He has enormous experience dealing local government affairs. In order to make UP self reliant he identified a number of ways and problems. This issue is very crucial to offer effective public eservice. At the same time it's a challenge as profusion of apprehension interrelated with this process such as making internal administration sound and effective, availability of manpower, impartially monitoring and evaluation of local resources and to have a quality relation with central government to get emergency support when needed. It's very important to categories service between UP and central government and should be specific in implementation. These are the challenges to make Up self-reliant. He was asked on the process by which level of dependency can be reduced. He focused on reviewing their past practices in relation to the use of financial indicators that created deficit and how it can be overcome should be pointed out and a capital improvement plan is required by which UP can identify sources of income and capital projects to be funded during the planning period. Besides UP chairman must have knowledge to prioritize current and future needs to fit within the anticipated level of financial resources and will arrange for better financial planning and will smooth the need for sharp increases in tax rates or user fees rationally. Then he mentioned the real fact that due to bureaucratic dominance over economic policies and programs at local level, the poor people are extremely dependent on government agencies for employment, health care, and other services. People think that effectiveness of local government is absent at their necessary which refrain them to be aware to pay to UP taxes, fees and tools. Moreover, they think the viable source of fees and charges for the UPs are trivial and not cost effective. He confessed fair of losing popularity if the put pressure on local people. In response of offering suggestion, he claimed that revenue collection process in local government needs restructuring every two or three years and UP should be allowed to share major tax bases to enable enough independent funds for development and it is essential to introduce measures to reduce bureaucratic power and provision of commission based tax collection system at local government for short periods may be ten years, can be an effective measure.

\section{Discussions of Findings}

In order for local governments to take advantage of using domestic resources, it must have acquiescence and competence to use it seeing that resources are the important bale for 
thriving administration. There are only three ways that a local government can reliably develop a surplus using their "own source revenues". They can reduce their expenditures. They can develop new sources of revenue. They can increase their "own source revenues" as currently defined. They can reduce their expenditures. They can develop new sources of revenue (Painter,2005). Union Parishad of Bangladesh are having several kinds of resources like forest resources, natural gas, coal, open fisheries, physical and infrastructural resources and financial resources like; taxes, fees, tolls, and development funds. If these potential resources are mobilized properly then their revenue system may be strong and will support Union Parishad financial sustainability. Financial resources are probably the most sought after local contribution, as they provide the ability to purchase a variety of goods and services at local area.

Local governments in developing countries derive their revenues from two principal sources: a) funds transferred to them from a higher level of government, and b) funds collected and retained in the locality itself (Painter, 2005). These are the major sources of fund of local government. Funds coming from higher levels of government are referred to as transfer payments and funds collected and retained in the locality itself are the local government's own source revenues. It is typical to find in Hilochia, Pirijpur and Sararchar Union of Bajitpur upazila that existing potential own source revenues are a small such as registrations of land, issuing certificates land registration fee and other fees. Fees are a revenue source directly associated with a particular local government service such as registrations, permits, or approvals. They are usually imposed on a per transaction basis, e.g. a fee of a fixed amount to register a property/marriage/birth. In order to increase revenue in Union Parishad, every potential sources of revenue is important to utilize which will ensure for improvement of services that currently provides. Leasing local Hatbazar, and Jalmahals ${ }^{\mathbf{5}}$ are promising area of income unfortunately get almost nothing from these sources. Issuing trade licenses has been found as a large part of income as well as fees from fair, exhibition and sports has been found as good source of income.

Local resources become a potential income source of UP but the officials of UP face various obstacles in maintaining their local resources such as lack of co-ordination and non co-operation of general people is the main barrier in maintaining local resources, political pressure and absence proper inspection are found as problems in this regard. Political leaders are interfering on their work. Shortage of manpower is another problem in maintaining their local resources as it affect the normal functions adversely. UP should make adequate preparations for resource mobilization to be effective and to ensure they are maximizing all opportunities but UP has no permanent tax collector post. Resource mobilization strategies, in this case, only internally, at the level of the executive head or the deputy to appoint a permanent or temporary tax collector on a percentage basis as the current collection rate in

\footnotetext{
5 Bazaar means a permanent enclosed merchandising area. Market place or street of shops where goods and services are exchanged or sold and Hat; used to refer to a particular role or occupation of someone who has more than one and Jal Mahal means "Water Palace" a low-lying area of land that is saturated with moisture, especially when regarded as the natural habitat of wildlife. Marshes, swamps, and bogs are examples of wetlands.
} 
assigned sources are not enough. The reason of collecting low amount of taxes and fees is largely depend on the dealing of public representatives because sometimes they are reluctant to collect taxes for fear of losing popularity. If they have a permanent tax collector, the general people will be familiar with this person and thus UP could be more self reliant. The owners of the local businesses at local area are not interested to shell out the tax. They explained various apologies that state of their business are hankering after awful situation and some business property like poultry firm, beauty parlor, brick field etc don't pay tax proportionally based on their capital. But that fact is lack of proper inspection and monitoring as well as shortage of sufficient manpower and transportation facilities is found major problem in maintaining their resources.

Local Government Institutions (LGIs) play a key role in the development of the rural economy and contribution towards poverty alleviation and promotion of economic growth is vital for national development. But the study revealed that the UP is not having sufficient strength to bear its expenses where making rural area developed by UP is far from reality at present in Bangladesh. The officials of UP also claimed that they face lots of problems at the time of leasing of Hatbazar and Jalmahal, accumulating of business tax etc. local political leaders want to influence to get a fixed amount of percentage of leasing money.

From the observation, in order to make UP self reliant; administration control and political pressure in UP has become a defector rule which threat the mobilization of local resources influencing on the decision-making processes of the UP; therefore it must be reduced and controlled through legal strength to collect fees, tools and limited tax at local level. Central government attempts to control development program run by the UP, so it needs to expand its existing income sources. Despite lack of UP autonomy, it is found that the positive role played by UP can trigger the collection of holding tax until the full utilization and increase of rate of the source while at a certain point, tax will remain same due to fixed nature of real property and have little chance to generate cash, especially in rural areas. UP functionaries are authorized sufficient power and responsibilities in this rule that can be utilized for strengthening local resources mobilization.Local government elected representatives in key processes of transparent, accountable and effective governance but it is found that the officials of UP are not accountable to the general people. They do not convey and share initiative to the general people at the time of implementing development activities.

The devolution of functions concerning UP development increases the demand and responsibilities for Monitoring \& Evaluation ${ }^{6}$ that is why needs to care for their own strategic and operational development planning, there is the need to trace development on these levels and to create the necessary data basis for decision-making.Training is very important to increase the technical capacity of the members of the UP although training needs assessment of the elected members of the local government has not yet been formally undertaken by any agency of the government. The study found that if training is made

\footnotetext{
6 Monitoring and evaluation (M\&E) is a process that helps improving performance and achieving results. Its goal is to improve current and future management of outputs, outcomes and impact.
} 
relating to resource mobilization then elected representatives, UP personnel and staffs will have scope to know more about the functional and operational aspects of the UP's role and activities.

The study findings also claim that local government revenue generation in Bangladesh needs restructuring so that taxing powers be given to local authorities and also UP should be allowed to share major tax bases with other levels of government to enable enough independent funds for development and it is essential to introduce measures to reduce bureaucratic power, debureaucratizing local institutions, and establish a genuinely representative local government system. The transfer of authority and power from government and corporate bureaucracies to representative local institutions must be effective to ensure local-level to mobilize local resources.

\section{Conclusion and tentative implications for policy}

Local government's resources mobilization and utilization in Bangladesh is one of the most keenly contested issues in Bangladesh and local government receives statutory allocations from the central government. As the lowest tier of local government body, UP can implement activities for identifying potential areas of resource mobilization. Local own revenues are a necessary but not a sufficient condition for to be self reliant because there are various factors involved. UP can barely exercise financial authority that they have to mobilize their own resources because of central dominance. Consequently, they had never been financially solvent due to shortage of adequate manpower, absence of proper tax assessment, fear of losing popularity among the UP members, predominant tax evading culture, perceived weaker correlation between tax payment and service delivery, and inadequacy of sources of income. It is found that the viable source of fees and charges for the UPs are trivial and not cost effective. However, it is impossible to realize national development goals without proper and accelerated local government. Therefore, UP should try to raise own financial resources to the optimum level from the existing bases, so that, more development schemes can be implemented in rural areas than the thwarting position now prevailing. A pragmatic policy approach is required, which may imply centralization of certain issues, such as management of property titles, valuation assessments of local resources, etc. Besides some more suggestion can be sorted out based on the study observation, Local government system in Bangladesh needs a moderate amount of financial autonomy to be able to discharge its responsibilities effectively.

In summary, it is evident from findings that UP revenue generation needs restructuring so that revenue collection powers be given to UP and also should be allowed to share major tax bases with other levels of government to enable enough independent funds for development and will need to operate much more effectively, corporately and with strong political engagement. UP functionaries can collect tax directly and at the same time they can appoint temporary commission based tax collectors. Based on the knowledge gaps identified in this study suggest areas for further research on local government taxation in UP. The strategy to enhance resource mobilization and increase the UP own source revenue hinges on introduce measures to reduce bureaucratic power, debureaucratize local institutions, and establish a 
genuinely representative local government system. The increase in revenue from UP statutory allocations definitely enhanced their economic fortunes and service delivery ability.

\section{Acknowledgements}

I would like to appreciate the invaluable support I received from my student Methia Akter Hredhi, Masters student at Shahjalal University of Science and Technology,Sylhet

\section{References}

Ahmed, M U.) Framework for a Strategy of UP Revenue/Resource Mobilization Piloting 2010.[Online]Available:

http://www.undp.org.bd/projects/prodocs/LGSP/Framework\%20for\%20a\%20Strategy\%20of $\%$ 20UP\%20Revenue\%20Resource\%20Mobilization\%20Piloting.pdf accessed on 26-03-2013)

Blair, W Harry. (ed.) Can Rural Development be financed from below? Local Resource Mobilization in Bangladesh, The University press limited, Dhaka,1989.

[3]Blair, W Harry. (ed.) Research Findings. In Blair W. Harry (ed), Can rural development be financed from below? Local resources mobilization in Bangladesh, University press, Dhaka,1989.

Bird, R. 'Sub-national Taxation in Developing Countries: A Review of the Literature.' Policy Research Working Paper 5450. (Washington D.C.: World Bank),2010.

Haque M. Shamsul. "Editorial Introduction Local Governance in Developing Nations: Reexamining the Question of Accountability" Regional Development Dialogue, Vol.18, No.2, 1997, pp.iii-xxiii. http://profile.nus.edu.sg/fass/polhaque/local\%20govt.pdf

Hye, Hasnat Abdul. (ed.) Decentralization Local Government Institutions and Resource Mobilization,Bangladesh Academy for Rural Development, Comilla.

http://en.wikipedia.org/wiki/Bajitpur_Upazila(accessed on 27-04-2013)

Martinez Vázques, J. \& Smoke, P. (2010) 'Introduction' Chapter 1 (pp. 11-21) in Local government finance: the challenges of the 21st century. Second Global Report on Decentralization and Local Democracy. (Barcelona: United Cities and Local Governments) 1985.

Olowu, D \& Wunsch, J. S "Local Governance in Africa: The Challenges of Democratic Decentralization”(Boulder: Lynne Rienner) 2003.

Painter, David L. 2005, “Local Resource Mobilization” Supporting Local Governance in the ANE Region: Fostering Multi-sectoral Approaches Workshop,Cairo, Egypt. Retrieved from http://www.tcgillc.com/tcgidocs/paper_painter.pdf 


\section{Macrothink}

Journal of Public Administration and Governance ISSN 2161-7104 2015, Vol. 5, No. 2

Rahman, Maksadur. "The Local Self Government in Bangladesh", Rajshahi University Text Book Board-Second edition, Rajshahi 1995.

Siddiqui, Kamal. "Local Government in Bangladesh"s The University press Limited, Dhaka, 2005 .

Ulla, Anwar. Financial Resources Mobilization Performance of Rural Local Government: Case Study of Three Union Parishad in Bangladesh 2010 [Online]Available: http://ccsenet.org/journal/index.php/ass/article/view/6741 accessed on 25-03-2013)

Ulla, Anwar. "Revenue Mobilization Performance of Union Parishad in Bangladesh: Is It Convergence of central-local relations"?2011 [Online]Available: http://www.ccsenet.org/journal/index.php/ass/article/view/6972 accessed on 03-03-2013)

The National Institute of Local Government (NILG) 2009, Local Government Division, Dhaka, Bangladesh

UNDP 2009, UP Revenue Trend, [Online] Available: http://www.undp.org.bd accessed on 04-04-2013) 